\title{
Research on Mathematical Model P2P Online Credit Risk Evaluation Based on Data Processing
}

\author{
Jun Zhao ${ }^{\mathrm{a}}$ \\ School of Business, Macau University of Science and Technology, Macau 999078, China \\ aluciazj@163.com
}

Keywords: P2P credit, Data Processing, Evaluation Model, Mathematical Model.

\begin{abstract}
Comprehensive evaluation of artificial neural network is intended to establish closer to human thinking mode of qualitative and quantitative selection model, through the sample of pattern of learning, acquiring knowledge evaluation from experts, experience, subjective judgment and a tendency to target the importance of when to make a comprehensive evaluation of the supplier. The data are collected from the investment area, most of which are from the area of network operators with a total of 70 personal loans application records. The first 65 records from the model prediction examine the application of the neural networks and the last five records are for prediction which shows good result.
\end{abstract}

\section{Introduction}

We use back propagation method from artificial neural networks to find out the credit grade from the several inputs such as age, education, marriage, housing, career and violation. This numerical method was used by different research communities in different contexts, was discovered and rediscovered, until in 1985 it found its way into connectionist. Comprehensive evaluation of artificial neural network is intended to establish closer to human thinking mode of qualitative and quantitative selection model, through the sample of pattern of learning, acquiring knowledge evaluation from experts, experience, subjective judgment and a tendency to target the importance of when to make a comprehensive evaluation of the supplier.

\section{Literature References}

Shidler adopts a computerized system creating and pricing synthetic credit products (Bauman et al., 2008). Huang and Huang draw the conclusion by adjusting each models consistent with data on the historical default loss experience that there is robust across structural models (Huang \& Huang, 2012). Forsythe finds out the obstacles for the consumers' reluctance to purchase online (Forsythe \& Shi, 2003). Atiya reviews the bankruptcy prediction using neural network models (Atiya, 2001). Jimenez, Ongena, Peydro and Saurina identify the effects of monetary policy analyzing the granting of loan applications from the concurrent changes (Jiménez, Ongena, Peydró, \& Saurina, 2014). Altman, Resti and Sironi develops the credit risk models treating the RR and its relationship with PD (Altman, Resti, \& Sironi, 2004). Andersson, Mausser, Rosen and Uryasev examines a new method for credit risk optimization (Andersson, Mausser, Rosen, \& Uryasev, 2001). Jarrow and Turnbull discuss the two approaches to pricing credit risky instruments (Jarrow \& Turnbull, 2000). Allen and Carletti proves the relationship between the two sectors under the uniform demand bank faces for liquidity (Allen \& Carletti, 2006). He and Xiong shows the conflicts between the liquidity premium and default premium (He \& Xiong, 2012).

\section{Organization of the Text}

PPDai was established in June 2007 and called “Shanghai Financial Information Service Co., Ltd.”. It is headquartered in Shanghai international financial center as China's first P2P network credit lending platform. PPDai is also the first special approval platform by the Department of Industry and 
Commerce and obtained financial information services qualification. The data are collected from the investment area, most of which are from the area of network operators with a total of 70 personal loan application records. The first 65 records from the model prediction examine the application of the neural networks and the last five records are for prediction which shows good result. The transfer function and error function are as followed:

Threshold transfer function

$$
f(u)=\left\{\begin{array}{l}
1, u \geq 0 \\
0, u<0
\end{array}\right.
$$

Piecewise transfer function

$$
f(u)=\left\{\begin{array}{c}
1, u \geq 1 \\
a u+b,-1<u<1 \\
0, u \leq-1
\end{array}\right.
$$

Sigmoid transfer function

$$
f(u)=\frac{1}{1+e^{-a u}}=\left\{\begin{array}{l}
1, a \rightarrow+\infty \\
0, a \rightarrow-\infty
\end{array}\right.
$$

Error function, di(n) refers to the expected output of neuro i while Oi(n) the actual output of neuro $i$ at time $n$.

$$
\operatorname{Ei}(n)=\operatorname{di}(n)+\operatorname{Oi}(n)
$$

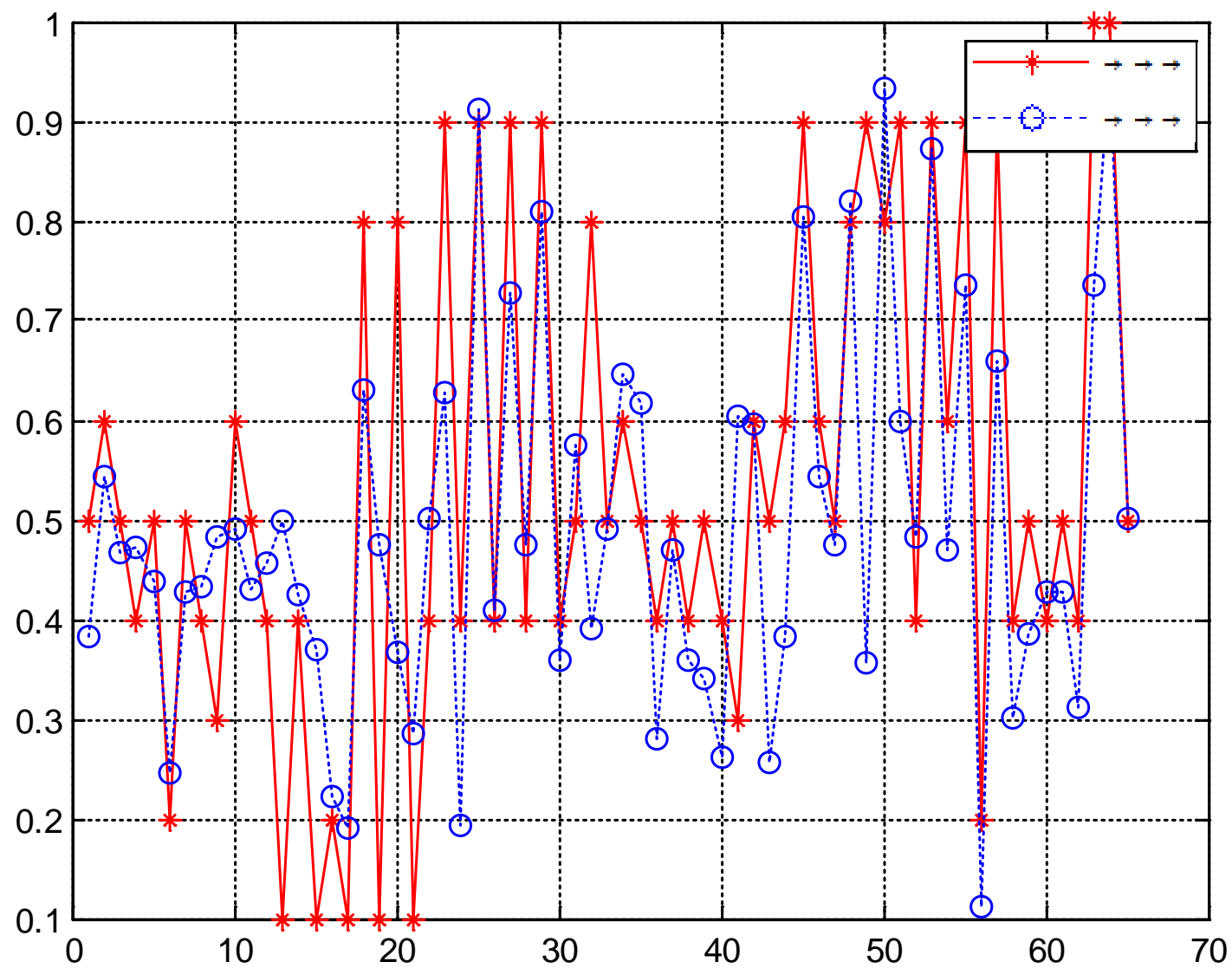

Fig.1 Training computation simulation result

The last five prediction turns out to be well fit for the actual output, most of which are 0.4 (with the actual output 0.5 ) and 0.9 (with the actual output 0.8 ). Assessment of the risk of lending money online platform and the radial BP neural network model based on the proposed network, etc., will be the new direction of research in artificial neural network model. Evaluation method based on neural networks cannot be replaced by other evaluation methods such as AHP, Fuzzy comprehensive evaluation and so on because learning neural network training sample model evaluation method needs resulting from the results of these methods. When evaluating condition changes (such as changes in the evaluation index system) the prediction must also be obtained by means of traditional methods of training samples of neural network models. 
Table 1 P2P personal credit risk evaluation system

\begin{tabular}{|c|c|c|c|c|c|c|c|c|}
\hline \multicolumn{9}{|l|}{ category } \\
\hline age & $20-25$ & $25-30$ & $30-35$ & $35-40$ & $40-45$ & $45-50$ & 50-55 & $\begin{array}{c}55 \\
\text { above }\end{array}$ \\
\hline value & 0.7 & 0.8 & 0.9 & 1 & 0.9 & 0.8 & 0.7 & 0.6 \\
\hline marriage & unmarried & & & married & & & divorced & \\
\hline value & 0.5 & & & 1 & & & 0 & \\
\hline education & primary & $\begin{array}{l}\text { seconda } \\
\text { ry }\end{array}$ & high school & $\begin{array}{l}\text { unior } \\
\text { college }\end{array}$ & college & master & & \\
\hline value & 0 & 0.1 & 0.3 & 0.5 & 0.7 & 1 & & \\
\hline career & $\begin{array}{l}\text { individual, } \\
\text { small } \\
\text { private }\end{array}$ & & & $\begin{array}{c}\text { private } \\
\text { business }\end{array}$ & & & $\begin{array}{c}\text { state-owned, } \\
\text { govt }\end{array}$ & \\
\hline & business & & & & & & & \\
\hline value & 0.5 & & & 0.7 & & & 1 & \\
\hline house & $\begin{array}{c}\text { parents } \\
\text { house }\end{array}$ & $\begin{array}{c}\text { rent } \\
\text { house }\end{array}$ & $\begin{array}{l}\text { commercial } \\
\text { and } \\
\text { residential }\end{array}$ & loan house & $\begin{array}{c}\text { no loan } \\
\text { house }\end{array}$ & & & \\
\hline value & 0.2 & 0.4 & 0.6 & 0.8 & 1 & & & \\
\hline violation & 50 above & $20-40$ & $10-20$ & Below 10 & none & & & \\
\hline value & 0 & 0.2 & 0.4 & 0.6 & 1 & & & \\
\hline credit & AA & A & B & $\mathrm{C}$ & D & $\mathrm{E}$ & $\mathrm{F}$ & \\
\hline value & 1 & 0.9 & 0.7 & 0.5 & 0.3 & 0.1 & 0 & \\
\hline
\end{tabular}

\section{Conclusion}

The private banks should focus on supporting small and micro enterprises, but based on the nature of the bank's lending for the purpose of profit, small and micro enterprise lending and repayment capacity is much higher than the risk of large-scale enterprise. Recommendations are given that there should be timely and effective measures to drop risky loans, strengthen loan management, establish hierarchical, strict credit access. Not only based a single indicator of some enterprises, but also there should be assessment according to the financial situation of enterprise multidimensional indicators of the impact of the financial situation, so the key steps and difficulty of these methods are to identify and assess the model selection index system, such as statistical methods, expert system and neural network technology.

\section{References}

[1] Allen, F., \& Carletti, E. Credit risk transfer and contagion. Journal of Monetary Economics, 2006, 53(1), 89-111.

[2] Altman, E., Resti, A., \& Sironi, A. Default recovery rates in credit risk modelling: a review of the literature and empirical evidence. Economic Notes, 2004, 33(2), 183-208.

[3] Andersson, F., Mausser, H., Rosen, D., \& Uryasev, S. Credit risk optimization with conditional value-at-risk criterion. Mathematical Programming, 2001, 89(2), 273-291.

[4] Atiya, A. F. Bankruptcy prediction for credit risk using neural networks: A survey and new results. Neural Networks, IEEE Transactions on, 2001, 12(4), 929-935.

[5] Bauman, J. P., Denton, R. L., Eberhardt, A. A., Hebblethwaite, W. E., Jasper, T. W., Margol, A., Whittaker, J. G. System for creating, pricing and managing and electronic trading and distribution of credit risk transfer products: Google Patents. 2008.

[6] Forsythe, S. M., \& Shi, B. Consumer patronage and risk perceptions in Internet shopping. Journal of Business Research, 2003, 56(11), 867-875. 
[7] He, Z., \& Xiong, W. Rollover risk and credit risk. The journal of finance, 2012, 67(2), 391-430.

[8] Huang, J.-Z., \& Huang, M. How much of the corporate-treasury yield spread is due to credit risk? Review of Asset Pricing Studies, 2012, 2(2), 153-202.

[9] Jarrow, R. A., \& Turnbull, S. M. The intersection of market and credit risk. Journal of Banking \& Finance, 2000, 24(1), 271-299.

[10] Jimenez, G., Ongena, S., Peydro, J. L., \& Saurina, J. Hazardous Times for Monetary Policy: What Do Twenty - Three Million Bank Loans Say About the Effects of Monetary Policy on Credit Risk - Taking? Econometrica, 2014, 82(2), 463-505. 